\title{
The 1-monolaurin inhibit growth and eradicate the biofilm formed by clinical isolates of Staphylococcus epidermidis
}

Andre Krislee ${ }^{1}$, Chaerul Fadly ${ }^{2}$, Dwi Aris Agung Nugrahaningsih ${ }^{2}$, Titik Nuryastuti ${ }^{3}$, Febri Odel Nitbani ${ }^{4}$, Jumina ${ }^{5}$ and Eti Nurwening Sholikhah ${ }^{2 *}$

From 3rd International Symposium on Congenital Anomaly and Developmental Biology 2019

Yogyakarta, Indonesia. 8-9 August 2019

\begin{abstract}
Background: Biofilm is one of the causes of antibiotic resistance. One of the biofilm-producing bacteria is Staphylococcus epidermidis which has been proven to infect long-term users of urinary catheters and implant devices. The 1-monolaurin compound has been known to have an antimicrobial effect. However, its effect on clinical isolates of S. epidermidis in producing biofilm has not been established. This study was conducted to investigate the effect of 1-monolaurin towards biofilm forming clinical isolates of S. epidermidis.

Methods: The experiment used micro broth dilution technique which consists of test group (1-monolaurin), positive control group (rifampicin), solvent group, negative control group (clinical isolate of S. epidermidis), and media group (TSB media). The Minimal Inhibition Concentration (MIC) was determined by incubating bacteria added with 1-monolaurin (1000-1953 $\mu \mathrm{g} / \mathrm{mL})$ or rifampicin $(250-0,488 \mu \mathrm{g} / \mathrm{mL})$ for $24 \mathrm{~h}$. The MIC was determined visually. After that, the incubated bacteria was cultured in TSA media to determine Minimal Bactericidal Concentration (MBC). The assessment of Biofilm inhibitory Concentration (BIC) and Biofilm Eradication Concentration (BEC) was conducted with the same way, the difference was BIC intervened directly with compound meanwhile BEC was incubated for $24 \mathrm{~h}$ in $37^{\circ} \mathrm{C}$ before the intervention. Then, the specimen was reincubated to grow biofilm at the microplate, washed with PBS and stained with $1 \%$ of crystal violet. The optical density (OD) was measured at a wavelength of $595 \mathrm{~nm}$. The percentage of BIC and BEC then were calculated, continued to probit analysis regression to determine the BIC50, BIC80, BEC50, and BEC80.
\end{abstract}

Results: The MIC dan MBC of 1-monolaurin and rifampicin were $>1000 \mu \mathrm{g} / \mathrm{mL},>1000 \mu \mathrm{g} / \mathrm{mL}, \leq 0.488 \mu \mathrm{g} / \mathrm{mL}$, and $1.953 \mu \mathrm{g} / \mathrm{mL}$ respectively. BIC50 and BIC80 of 1-monolaurin and rifampicin were $26.669 \mu \mathrm{g} / \mathrm{mL}, 168.688 \mu \mathrm{g} / \mathrm{mL}$, $0.079 \mu \mathrm{g} / \mathrm{mL}$, and $0.974 \mu \mathrm{g} / \mathrm{mL}$ respectively. The BEC50 and BEC80 of 1-monolaurin and rifampicin were $322.504 \mu \mathrm{g} /$ $\mathrm{mL}, 1338.681 \mu \mathrm{g} / \mathrm{mL}, 5.547 \mu \mathrm{g} / \mathrm{mL}$, dan $17.910 \mu \mathrm{g} / \mathrm{mL}$ respectively.

Conclusion: The 1-monolaurin can inhibit growth and eradicate the biofilm formed by clinical isolates of $S$. epidermidis, however, it has neither inhibit nor kill planktonic cells of S. epidermidis.

Keywords: Biofilm, Staphylococcus epidermidis, 1-monolaurin, MIC, MBC, BIC, BEC

\footnotetext{
* Correspondence: etinurweningsholikhah@ugm.ac.id

${ }^{2}$ Departement of Pharmacology and Therapy Faculty of Medicine, Public

Health, and Nursing, Universitas Gadjah Mada, Yogyakarta, Indonesia

Full list of author information is available at the end of the article
}

(c) The Author(s). 2019 Open Access This article is distributed under the terms of the Creative Commons Attribution 4.0 International License (http://creativecommons.org/licenses/by/4.0/), which permits unrestricted use, distribution, and reproduction in any medium, provided you give appropriate credit to the original author(s) and the source, provide a link to the Creative Commons license, and indicate if changes were made. The Creative Commons Public Domain Dedication waiver (http://creativecommons.org/publicdomain/zero/1.0/) applies to the data made available in this article, unless otherwise stated. 


\section{Background}

Naturally, microorganisms attach to and grow in living and inanimate surface, such as enamel, cardiac valve, lung, middle ear as well as medical devices. The appearance of microorganisms growth that often occurs is biofilm formation. Microorganism produces Extracellular Polymeric Substance (EPS) that facilitate attachment and biofilm formation as a result change host phenotype. Biofilm has become a serious health problem because of the increased resistance to antibacterial and its potential to cause infection in patients using medical equipment. There are at least three reasons why biofilms can cause antibiotic resistance: (1) antibiotic agents diffuse into EPS matrix and become inactive, (2) biofilms reduce microorganism growth rates that affect antibiotic inactivation, and (3) the environment around cells protects the organism, such as decrease antibiotic uptake into cells [1].

Biofilm formation process through five stages. The first stage includes an initial attachment that can occur actively or passively. This process depends on the physicochemical components of bacteria and their surface components. At this stage, the bacteria still inherently reversible. Furthermore, the bacteria will attach irreversibly. In this second stage, the release of biofilms attachment requires strong strengths such as detergent, surfactant, sanitizer and/or heating. The third stage has entered the initial process of establishing an architecture of biofilm (microcolony formation). Microcolony formation resulted from the accumulation and growth of microorganisms and the production of EPS. This strengthens the bacterial bond with the host. Then, it will enter the biofilm maturation stage, the fourth stage, which develope at least 10 days or more. The last stage is the dispersion stage. At this stage, bacterial cells will return to their planktonic cells and come out of the biofilm to form new colonies [2].

Some microorganisms that can form biofilms are gram-positive bacteria, such as Staphylococcus aureus and Staphylococcus epidermidis, gram-negative bacteria including Pseudomonas aeruginosa, Escherichia coli and several genus Candida especially Candida albicans and Candida tropicalis [3]. One of the species will be discussed here is $S$. epidermidis which is a gram-positive bacteria coagulase-negative staphylococci group [4].

Staphylococcus epidermidis is a commensal bacteria that colonize in the skin and mucous membranes of humans and other mammals. The colony of S. epidermidis predominantly in axillae, head, and nares. As science develops, $S$. epidermidis has been proven to often contaminate medical devices, especially in peripheral and central catheter placement. Besides, these bacteria play a role in infection of prosthetic joints, vascular grafting, surgery, cranial nerve system shunts, and cardiac devices [5].
The mechanism of $S$. epidermidis in forming biofilms is through the biochemical and molecular process. Polysaccharides adhesin have an important role in this biochemical process. The two main polysaccharides produced by $S$. epidermidis are capsular polysaccharide adhesin (PSA) and polysaccharide intercellular adhesin (PIA). The PSA plays a role in initiation attachment and PIA play role in cell accumulation. The PIA itself is coded by the intercellular adhesin (ica) gene [6]. More than $85 \%$ of $S$. epidermidis isolated bacteria from blood cultures of the patient in hospitals have the ica gene [7]. In Addition, the $S$. epidermidis was the third main bacteria at Fatmawati Hospital that often obtained from the culture of patients entering the Intensive Care Unit (ICU) after P. aeruginosa and K. Pneumonia [8]. Therefore antibiotics against $S$. epidermidis especially the clinical isolate is needed.

Natural compounds are known to be potential for new antibiotic [9]. One of the natural compounds that have been shown have an antibacterial activity is 1-monolaurin. The 1-monolaurin is a compound derived from coconut oil. Some bacteria that have been proven to be inactivated by monolaurin are Liseteria monocytogenes, Helicobacter pylori, Hemophilus influenza, Staphylococcus aureus, Streptococcus groups A, B, F, and G [10]. However, the antibacterial and antibiofilm activity, especially inhibition and bactericidal of planktonic cells and inhibition and eradication of biofilms from 1-monolaurin against clinical isolates of $S$. epidermidis is unknown.

\section{Materials and methods Materials}

The 1-monolaurin was obtained from Nitbani [11]. The isolates of $S$. epidermidis obtained from the collection of Microbiology Laboratory Faculty of Medicine, Public Health, and Nursing UGM. The Dimethyl Sulfoxide (DMSO), $\mathrm{NaCl}$, violet crystal, $96 \%$ of ethanol, Phosphate Buffered Saline (PBS) with pH of 7.4, TSB media, and TSA media were obtained from Microbiology Laboratory inventory, Faculty of Medicine, Public Health, and Nursing UGM. The 96-well microplate with a flat-shaped base from Biosigma, Italian and U-shaped base from Iwaki, Japan.

\section{Methods}

\section{Preparing 1-monolaurin}

The 1-monolaurin was prepared by mixing $2 \mathrm{mg}$ with $50 \mu \mathrm{g} / \mathrm{mL}$ of pure DMSO and $950 \mu \mathrm{g} / \mathrm{mL}$ TSB media then being vortex to produce 1-monolaurin dissolved in $5 \%$ of DMSO as stock solution. The various concentration of 1-monolaurin was made from this stock solution.

Preparing clinical isolate of Staphylococcus epidermidis The clinical isolate of bacteria producing biofilm S. epidermidis was prepared in suspension by mixing the 
pellets of S. epidermidis clinical isolates with $0.9 \%$ sterile $\mathrm{NaCl}$. The clarity of the mixture was compared with McFarland 0.5. Furthermore, the suspension was diluted with TSB media with a ratio of $1: 100$. The bacterial suspension was prepared in a concentration of $1 \times 10^{6}$ $\mathrm{CFU} / \mathrm{mL}$.

\section{Minimum inhibitory concentration and minimum bactericidal concentration assay}

The Minimum inhibitory concentration (MIC) and Minimum Bactericidal Concentration (MBC) assay were conducted using micro broth dilution assay [12]. The $\mathrm{MIC}$ is the lowest level of the compound which can inhibit the growth of bacterial planktonic cells, while MBC is the lowest level of a compound that can kill $99.9 \%$ of bacterial planktonic cells. The 1-monolaurin or rifampicin at various concentration were filled triplicate to each well of a flat-shaped microplate, and the same volume of suspension of $S$. epidermidis clinical isolates were added. The final concentration of 1-monolaurin in the plate was $1000-1.953 \mu \mathrm{g} / \mathrm{mL}$ and $250-0.488 \mu \mathrm{g} / \mathrm{mL}$ for rifampicin. After $24 \mathrm{~h}$ incubation at $37^{\circ} \mathrm{C}, \mathrm{MIC}$ was determined visually by observing the presence or absence of planktonic cell growth. The final MIC value is the mode value of the MIC in each well. The MBC was determined by adding $10 \mu \mathrm{L}$ of liquid from a clear well to the TSA media, after $24 \mathrm{~h}$ incubation at $37^{\circ} \mathrm{C}$ by observing whether there was bacterial growth in TSA media.

\section{Biofilm inhibitory concentration assay}

Biofilm inhibitory Concentration (BIC) assay was conducted by microtiter plate assay [13]. Biofilm inhibitory testing used a microplate with a U-shaped base with the volume in each well was $100 \mu \mathrm{L}$. Biofilm testing procedures have the same procedures with planktonic cell testing, the difference was after microplates were incubated, microplates were washed with PBS to separate the formed biofilm, and was given $1 \%$ of crystal violet, then washed again with PBS and finally was given $96 \%$ of alcohol and left for $15 \mathrm{~min}$. All experiments were carried out in triplicate. The Optical Density (OD) was measured at a wavelength of $595 \mathrm{~nm}$. The percentage of biofilm inhibitory was calculated using the following formula: [(OD growth control - OD sample) / OD growth control] $\times 100$ [14]. Then, the biofilm formation inhibition such as BIC50 and BIC80 were determined by probit analysis regression [15].

\section{Biofilm eradication concentration assay}

Biofilm Eradication Concentration (BEC) Assay was conducted by the same procedures as the BIC assay. The biofilm eradication testing was started by growing the biofilm first by incubating the suspension of S. epidermidis clinical isolates for $24 \mathrm{~h}$ at $37^{\circ} \mathrm{C}$. Then, each well of microplate was washed with PBS with $\mathrm{pH}$ of 7.4 so that it leaves only the biofilm and the 1-monolaurin or rifampicin with various concentration was added. After that, the microplate was incubated for $24 \mathrm{~h}$ at $37^{\circ} \mathrm{C}$ and was washed with PBS, add $1 \%$ of crystal violet and was washed again with PBS and finally 96\% alcohol was given and left for $15 \mathrm{~min}$. All experiments were conducted in triplicate and three data were generated in each experiment. The Optical Density (OD) was measured at a wavelength of $595 \mathrm{~nm}$. The percentage of biofilm eradication was calculated using the following formula: [(OD growth control - OD sample) / OD growth control] $\times$ 100 [14]. Then, the biofilm formation eradication such as BEC50 dan BEC80 were determined by probit analysis regression [15].

\section{Result}

The minimum inhibitory concentration (MIC) and minimum bactericidal concentration (MBC)

Table 1 showed the MIC and MBC of 1-monolaurin or rifampicin on planktonic cell of $S$. epidermidis clinical isolate.

\section{The biofilm inhibitory concentration (BIC)}

Biofilm growth inhibition testing of $S$. epidermidis clinical isolates described in BIC50 and BIC80 that was obtained from probit regression analysis shown in Table 2.

\section{The biofilm eradication concentration (BEC)}

The eradication biofilm formation activity of 1-monolaurin or rifampicin on $S$. epidermidis clinical isolates was presented in Table 3 . The BEC50 and BEC 80 were obtained by probit regression analysis.

\section{Discussion}

The 1-monolaurin cannot inhibit growth and kill planktonic cells of S. epidermidis clinical isolates at the highest concentrations tested. The rifampicin as a positive control, has been shown to have the effect of inhibiting growth and killing bacterial planktonic cells. This results in accordance with the reference of Clinical \& Laboratory Standards Institute [16]. In this this study, the MIC and $\mathrm{MBC}$ of rifampicin for planktonic cells of S. epidermidis clinical isolates were $\leq 0.488 \mu \mathrm{g} / \mathrm{mL}$ and $1.953 \mu \mathrm{g} /$ $\mathrm{mL}$. According to the CLSI [12], the S. epidermidis clinical isolate which used in this study showed its sensitivity to antibiotics. The solvent of 1-monolaurin compound

Table 1 The MIC and MBC of 1-monolaurin or rifampicin on planktonic cell of S. epidermidis clinical isolate

\begin{tabular}{lll}
\hline Compounds & MIC $(\mu \mathrm{g} / \mathrm{mL})^{a}$ & $\mathrm{MBC}(\mu \mathrm{g} / \mathrm{mL})$ \\
\hline 1 -monolaurin & $>1000$ & $>1000$ \\
Rifampicin & $\leq 0.488$ & 1.953 \\
\hline
\end{tabular}

${ }^{a}$ mode concentration of testing compound in triplicate test 
Table 2 The inhibition biofilm formation of 1-monolaurin or rifampicin on S. epidermidis clinical isolates

\begin{tabular}{|c|c|c|c|c|c|c|c|c|c|}
\hline \multirow{2}{*}{$\begin{array}{l}\text { S. epidermidis clinical isolate } \\
++\end{array}$} & \multirow{2}{*}{$\begin{array}{l}\text { TSB Media } \\
+\end{array}$} & \multirow{2}{*}{$\begin{array}{l}\text { Compound } \\
\mathrm{O}\end{array}$} & \multirow{2}{*}{$\begin{array}{l}\text { Concentration }(\mu \mathrm{g} / \mathrm{mL}) \\
-\end{array}$} & \multicolumn{3}{|c|}{$\mathrm{OD} \pm \mathrm{SD}$} & \multirow{2}{*}{$\begin{array}{l}\text { BIC } \\
(\%) \\
0\end{array}$} & \multirow{2}{*}{$\begin{array}{l}\mathrm{BIC50} \\
(\mu \mathrm{g} / \mathrm{mL}) \\
-\end{array}$} & \multirow{2}{*}{$\begin{array}{l}\begin{array}{l}\mathrm{BIC} 80 \\
(\mu \mathrm{g} / \mathrm{mL})\end{array} \\
-\end{array}$} \\
\hline & & & & 0.454 & \pm & 0.040 & & & \\
\hline $\mathrm{O}$ & + & O & - & 0.081 & \pm & 0.003 & 100 & - & - \\
\hline+ & + & $5 \%$ of DMSO & - & 0.456 & \pm & 0.020 & -0.537 & - & - \\
\hline \multirow[t]{10}{*}{+} & \multirow[t]{10}{*}{+} & \multirow[t]{10}{*}{ 1-monolaurin } & 1000 & 0.071 & \pm & 0.032 & 102.773 & \multirow[t]{10}{*}{26.669} & \multirow[t]{10}{*}{166.688} \\
\hline & & & 500 & 0.093 & \pm & 0.040 & 96.780 & & \\
\hline & & & 250 & 0.163 & \pm & 0.013 & 77.996 & & \\
\hline & & & 125 & 0.240 & \pm & 0.200 & 57.424 & & \\
\hline & & & 62.5 & 0.226 & \pm & 0.194 & 61.181 & & \\
\hline & & & 31.25 & 0.248 & \pm & 0.025 & 55.277 & & \\
\hline & & & 15.625 & 0.288 & \pm & 0.024 & 44.365 & & \\
\hline & & & 7.813 & 0.362 & \pm & 0.036 & 24.597 & & \\
\hline & & & 3.906 & 0.375 & \pm & 0.033 & 21.109 & & \\
\hline & & & 1.953 & 0.375 & \pm & 0.013 & 21.119 & & \\
\hline \multirow[t]{10}{*}{+} & \multirow[t]{10}{*}{+} & \multirow[t]{10}{*}{ Rifampicin } & 250 & 0.075 & \pm & 0.003 & 101.699 & \multirow[t]{10}{*}{0.079} & \multirow[t]{10}{*}{0.974} \\
\hline & & & 125 & 0.090 & \pm & 0.009 & 97.764 & & \\
\hline & & & 62.5 & 0.098 & \pm & 0.008 & 95.349 & & \\
\hline & & & 31.25 & 0.094 & \pm & 0.001 & 96.601 & & \\
\hline & & & 15.625 & 0.105 & \pm & 0.007 & 93.560 & & \\
\hline & & & 7.813 & 0.094 & \pm & 0.001 & 96.422 & & \\
\hline & & & 3.906 & 0.099 & \pm & 0.009 & 95.170 & & \\
\hline & & & 1.953 & 0.116 & \pm & 0.008 & 90.698 & & \\
\hline & & & 0.977 & 0.191 & \pm & 0.050 & 70.483 & & \\
\hline & & & 0.488 & 0.188 & \pm & 0.011 & 71.288 & & \\
\hline
\end{tabular}

used, 5\% of dimethylsulphoxide, did not show any effect on planktonic or biofilm cells. Other study using $10 \%$ of dimethylsulphoxide also showed that the $10 \%$ of dimethylsulphoxide did not show any effect on bacterial growth [14].

In contrast with testing on planktonic cell, both the 1-monolaurin and rifampicin have activity in inhibiting growth and eradicate the biofilm formation of $S$. epidermidis clinical isolate. As positive control in this study, the BIC50 and BIC80 of rifampicin were $0.079 \mu \mathrm{g} / \mathrm{mL}$ and $0.974 \mu \mathrm{g} / \mathrm{mL}$. These results were not different from previous studies that showed rifampicin had the effect of inhibiting biofilm formation at concentrations $<0.0625 \mu \mathrm{g} / \mathrm{mL}$ [17]. The BEC50 and BEC80 rifampicin were $5.547 \mu \mathrm{g} / \mathrm{mL}$ and $17.910 \mu \mathrm{g} /$ $\mathrm{mL}$. These results were not different from the study conducted by Laverty [18] which showed that rifampicin could eradicate biofilms at concentrations of $62.5 \mu \mathrm{g} / \mathrm{mL}$. This supports the Marquez [19] study which shows that rifampicin has a higher sensitivity to $S$. epidermidis compared to some antibiotics such as vancomycin, ceftaroline, erythromycin, fusidic acid, gentamicin, linezolid, and pristinamisin.
The minimum inhibitory concentration (MIC) and minimum bactericidal concentration (MBC) of 1monolaurin on $S$. epidermidis clinical isoloate was > $1000 \mu \mathrm{g} / \mathrm{mL}$. From the results of the previous studies [11] showed that 1-monolaurin can inhibit the formation of planktonic cells from other Staphylococcus groups, S. aureus at a concentration of $500 \mu \mathrm{g} / \mathrm{mL}$. Besides, a study conducted by Tangwathcharin [20] showed that compound 1-monolaurin required a concentration of $100 \mu \mathrm{g} /$ $\mathrm{mL}$ to kill $S$. aureus planktonic cells and their clinical isolates. Staphylococcus epidermidis has been shown to have a higher resistance to antibiotics than S. aureus [21].

Referring to Holetz [22] study, the compound with concentrations more than $1000 \mu \mathrm{g} / \mathrm{mL}$ did not have antimicrobial effects. This shows that 1-monolaurin does not have the effect of inhibiting or killing planktonic cells of $S$. epidermidis clinical isolates.

The results showed that 1-monolaurin can inhibit biofilm formation of $S$. epidermidis clinical isolates. The BIC50 and BIC80 1-monolaurin values were $26.669 \mu \mathrm{g} /$ $\mathrm{mL}$ and $168.688 \mu \mathrm{g} / \mathrm{mL}$. The 1-monolaurin can inhibit the formation of biofilms by reducing the hydrophobicity of bacterial cells and preventing attachment of bacterial 
Table 3 The eradication biofilm formation of 1-monolaurin or rifampicin on S. epidermidis clinical isolates

\begin{tabular}{|c|c|c|c|c|c|c|c|c|c|}
\hline \multirow{2}{*}{$\begin{array}{l}\text { S. epidermidis clinical isolate } \\
+\end{array}$} & \multirow{2}{*}{$\begin{array}{l}\text { TSB Media } \\
+\end{array}$} & \multirow{2}{*}{$\begin{array}{l}\text { Compound } \\
\mathrm{O}\end{array}$} & \multirow{2}{*}{$\begin{array}{l}\text { Concentration }(\mu \mathrm{g} / \mathrm{mL}) \\
-\end{array}$} & \multicolumn{2}{|c|}{$\mathrm{OD} \pm \mathrm{SD}$} & \multicolumn{2}{|l|}{$\begin{array}{l}\text { BEC } \\
(\%)\end{array}$} & \multirow{2}{*}{$\begin{array}{l}\mathrm{BEC50} \\
(\mu \mathrm{g} / \mathrm{mL}) \\
-\end{array}$} & \multirow{2}{*}{$\begin{array}{l}\begin{array}{l}\text { BEC80 } \\
(\mu \mathrm{g} / \mathrm{mL})\end{array} \\
-\end{array}$} \\
\hline & & & & 0.463 & \pm & 0.041 & 0 & & \\
\hline O & + & O & - & 0.106 & \pm & 0.006 & 100 & - & - \\
\hline+ & + & DMSO 5\% & - & 0.476 & \pm & 0.090 & -3.641 & - & - \\
\hline \multirow[t]{10}{*}{+} & \multirow[t]{10}{*}{+} & \multirow[t]{10}{*}{ 1-monolaurin } & 1000 & 0.165 & \pm & 0.018 & 83.380 & \multirow[t]{10}{*}{322.504} & \multirow[t]{10}{*}{1338.681} \\
\hline & & & 500 & 0.219 & \pm & 0.039 & 68.161 & & \\
\hline & & & 250 & 0.363 & \pm & 0.064 & 27.918 & & \\
\hline & & & 125 & 0.398 & \pm & 0.033 & 18.114 & & \\
\hline & & & 62.5 & 0.372 & \pm & 0.070 & 25.397 & & \\
\hline & & & 31.25 & 0.423 & \pm & 0.082 & 11.111 & & \\
\hline & & & 15.625 & 0.433 & \pm & 0.064 & 8.403 & & \\
\hline & & & 7.813 & 0.465 & \pm & 0.077 & -0.654 & & \\
\hline & & & 3.906 & 0.465 & \pm & 0.038 & -0.654 & & \\
\hline & & & 1.953 & 0.392 & \pm & 0.082 & 19.701 & & \\
\hline \multirow[t]{10}{*}{+} & \multirow[t]{10}{*}{+} & \multirow[t]{10}{*}{ Rifampicin } & 250 & 0.118 & \pm & 0.010 & 96.452 & \multirow[t]{10}{*}{5.547} & \multirow[t]{10}{*}{17.910} \\
\hline & & & 125 & 0.114 & \pm & 0.011 & 97.666 & & \\
\hline & & & 62.5 & 0.107 & \pm & 0.002 & 99.720 & & \\
\hline & & & 31.25 & 0.123 & \pm & 0.011 & 95.238 & & \\
\hline & & & 15.625 & 0.204 & \pm & 0.016 & 77.362 & & \\
\hline & & & 7.813 & 0.221 & \pm & 0.052 & 67.787 & & \\
\hline & & & 3.906 & 0.278 & \pm & 0.060 & 51.727 & & \\
\hline & & & 1.953 & 0.394 & \pm & 0.100 & 19.328 & & \\
\hline & & & 0.977 & 0.450 & \pm & 0.105 & 3.548 & & \\
\hline & & & 0.488 & 0.466 & \pm & 0.121 & 2.708 & & \\
\hline
\end{tabular}

cells [23]. If the bacteria is too hydrophobic or hydrophilic it can cause damage to the biofilm structure [24]. The inhibitory effect was similar to the Schlievert [25] study which showed monolaurin had a $66 \%$ inhibitory effect on $S$. aureus biofilm at a concentration of $48 \mu \mathrm{g} /$ $\mathrm{mL}$ monolaurin. Besides, monolaurin can inhibit biofilm formation in other bacteria such as S. mutans which is the main bacterium on human dental plaques at a concentration of $95 \mu \mathrm{g} / \mathrm{mL}$ [23].

The results showed that 1 -monolaurin can eradicate the formation of biofilm S. epidermidis clinical isolate. The BEC50 and BEC80 1-monolaurin values were 322.504 $\mu \mathrm{g} /$ $\mathrm{mL}$ and $1338.681 \mu \mathrm{g} / \mathrm{mL}$. Its seems like the Goc [26] study which showed that monolaurin can eradicate $50 \%$ of biofilm formation from Borrelia sp. at a concentration of $375 \mu \mathrm{g} / \mathrm{mL}$. From previous studies, it was found that monolaurin can change the morphological structure of biofilms which are similar to proteolytic enzyme activity (proteases and phospholipases) [27].

The interesting thing to discuss is that 1-monolaurin requires a higher concentration for inhibit and kill the planktonic cells of $S$. epidermidis clinical isolates than inhibit and eradicate $S$. epidermidis biofilm isolates. This is different from the Donlan ${ }^{1}$ study which showed that biofilms increased antimicrobial resistance. Compared to monolaurin studies on Borellia sp., it also shows the MIC and $\mathrm{MBC}$ values which are lower than the BEC50 value [25]. The explanation of fact in our research is 1monolaurin compound needs higher effort or higher concentration when it interacts with cell wall of the planktonic cells of S. epidermidis clinical isolates. S. epidermidis is Gram positive bacteria that have several layers of peptidoglycan in its cell wall. Therefore, 1-monolaurin with higher concentration is needed to destroy the cell wall of S. epidermidis. In contrast, a biofilm isolates of S. epidermidis is a substance (single substance) produced by this bacteria to protect its self or its coloni. So, 1-monolaurin as an antibiofilm agent is needed in a slower concentration to interact with biofilm $S$. epidermidis. 1-Monolaurin compound shows its high ability as antibiofim to inhibit and kill S. epidermidis biofilm isolates because its have a lauril group (lipophilic side) and 2 hydroxyl group (hydrophilic side). The two different groups in monolaurin structure can interact with the lipophilic and the hydrophobic substance in $S$. epidermidis biofilm isolates through Hydrogen and Van de Waals interaction. 


\section{Conclusions}

The 1-monolaurin can inhibit growth and eradicate the biofilm formed by clinical isolates of $S$. epidermidis, however it has neither inhibit nor kill planktonic cells of S. epidermidis. These findings showed that the 1-monolaurin potential as antibiotics against clinical isolates of $S$. epidermidis.

\section{Abbreviations}

BEC: Biofilm eradication concentration; BIC: Biofilm inhibitory concentration; CFU/mL: Colony-forming units per mililiter; CLSI: Clinical \& laboratory standards institute; DMSO: Dimethyl sulfoxide; EPS: Extracellular polymeric substance; ICU: Intensive care unit; MBC: Minimal bactericidal concentration MIC: Minimal inhibition concentration; OD: Optical density; PBS: Phosphate buffered saline; PIA: Polysaccharide intercellular adhesin; PSA: Polysaccharide adhesin; TSA: Tryptic soy agar; TSB: Tryptic soy broth

\section{Acknowledgments}

The author thanks to Mrs. Sunyi and Mrs. Mulyani for laboratory assistance.

\section{About this supplement}

This article has been published as part of BMC Proceedings Volume 13 Supplement 11, 2019: Selected articles from the 3rd International Symposium on Congenital Anomaly and Developmental Biology 2019 (ISCADB 2019). The full contents of the supplement are available online at https://bmcproc. biomedcentral.com/articles/supplements/volume-13-supplement-11.

\section{Authors' contributions}

AK, CF, and ENS designed the study. AK and TN carried out the laboratory work. FON and J synthesized the compounds. DAA and EN analyzed the data. AK and ENS wrote the manuscript. All authors read and approved the final version of the manuscript.

\section{Funding}

The study and publication costs are funded by Faculty of Medicine, Public Health, and Nursing Universitas Gadjah Mada Yogyakarta, Indonesia.

\section{Availability of data and materials}

The data used to support the findings of this study are available from the corresponding author upon request.

\section{Ethics approval}

The letter of The Medical and Health Research Ethics Committee of Faculty of Medicine - Dr. Sardjito General Hospital Yogyakarta Indonesia with reference no KE/FK/0089/EC/2018 stated that this research not need approval letter.

\section{Consent for publication}

Not applicable.

\section{Competing interests}

The authors declare that they have no competing interests.

\section{Author details}

${ }^{1}$ Faculty of Medicine, Public Health, and Nursing, Universitas Gadjah Mada, Yogyakarta, Indonesia. ${ }^{2}$ Departement of Pharmacology and Therapy Faculty of Medicine, Public Health, and Nursing, Universitas Gadjah Mada, Yogyakarta, Indonesia. ${ }^{3}$ Departement Microbiology, Faculty of Medicine, Public Health, and Nursing, Universitas Gadjah Mada, Yogyakarta, Indonesia. ${ }^{4}$ Departement of Chemistry, Faculty of Science and Engineering, Universitas Nusa Cendana, Kupang, Indonesia. ${ }^{5}$ Departement of Chemistry, Faculty of Mathematics and Natural Sciences, Universitas Gadjah Mada, Yogyakarta, Indonesia.

Published: 16 December 2019

\section{References}

1. Donlan R. Biofilm formation: A clinically relevant microbiological process. Clin Infect Dis. 2001;33(8):1387-92.

2. Srey S, Jahid I, Ha S. Biofilm formation in food industries: A food safety concern. Food Control. 2013;31(2):572-85.
3. Hawser S, Lociuro S, Islam K. Dihydrofolate reductase inhibitors as antibacterial agents. Biochem Pharmacol. 2006;71(7):941-8.

4. Levinson W. Review of medical microbiology and immunology. 12th ed. New York: McGraw-Hill Medical; 2012. p. 109-16.

5. Otto M. Staphylococcus epidermidis-the "accidental" pathogen. Nat Rev Microbiol. 2009;7(8):555-67.

6. O'Gara JP, Humphreys H. Staphylococcus epidermidis biofilm: importance and implications. J Med Microbiol. 2001;50:582-7.

7. Ziebuhr W, Meyer P, Heilmann C, Go F, Wilms K, Straube E, et al. Detection of the intercellular adhesion gene cluster (Ica) and phase variation in Staphylococcus epidermidis blood culture strains and mucosal isolates. Infect Immun. 1997;65(3):890-6.

8. Radji M, Fauziah S, Aribinuko N. Antibiotic sensitivity pattern of bacterial pathogens in the intensive care unit of Fatmawati hospital, Indonesia. Asian Pac J Trop Biomed. 2011;1(1):39-42.

9. Moloney. Natural product as a source for novel antibiotics. Trends Pharmacol Sci. 2016;37(8):689-701.

10. Lieberman S, Enig M, Preuss H. A review of monolaurin and Lauric acid:natural Virucidal and bactericidal agents. Altern Complem Ther. 2006;12(6):310-4.

11. Nitbani FO, Jumina J, Siswanta D, Sholikhah EN, Fitriastuti D. Synthesis and antibacterial activity 1-monolaurin. Orient J Chem. 2016;34(2):863-7.

12. Clinical \& Laboratory Standards Institute (CLSI). M07-A9 method for dilution antimicrobial susceptibility test for bacteria that grow aerobicallyApproved Standart. 9th ed. Wayne: Clinical and Laboratory Standards Institute; 2012.

13. Azeredo J, Azevedo N, Briandet R, Cerca N, Coenye T, Costa A, et al. Critical review on biofilm methods. Crit Rev Microbiol. 2016:43(3):313-51.

14. Nikolić M, Vasić S, Stefanović O, Čomić L. Antibacterial and anti-biofilm activity of ginger (Zingiber Officinale (roscoe)) ethanolic extract. Kragujevac J Sci. 2014;36:129-36.

15. Astuti P, Saifullah T, Wulanjati M, Yosepine A, Ardianti D. Basil essential oil (Ocimum basilicum L.) activities on streptococcus mutans growth, biofilm formation and degradation and its stability in micro-emulsion mouthwash formula. Int J Phar Clin Res. 2016;8(1):26-32.

16. Clinical \& Laboratory Standards Institute (CLSI). M100 performance standards for antimicrobial. Wayne: Clinical and Laboratory Standards Institute; 2018.

17. Hall Snyder AD, Vidaillac C, Rose W, McRoberts JP, Rybak MJ. Evaluation of highdose Daptomycin versus vancomycin alone or combined with clarithromycin or rifampin against Staphylococcus aureus and S. epidermidis in a novel in vitro PKV PD model of bacterial biofilm. Infect Dis Ther. 2014;4(1):51-65.

18. Laverty G, Alkawareek M, Gilmore B. The in vitro susceptibility of biofilm forming medical device related pathogens to conventional antibiotics. Dataset Papers in Science. 2014. https://doi.org/10.1155/2014/250694.

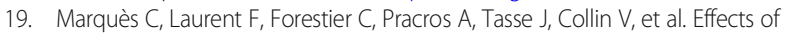
antibiotics on biofilm and unattached cells of a clinical Staphylococcus aureus isolate from bone and joint infection. J Med Microbiol. 2015;64(9):1021-6.

20. Tangwatcharin P, Khopaibool P. Activity of virgin Coconot oil, lauric acid or monolaurin in combination with lactic against Staphylococcus aureus. Southeast Asian J Trop Med Public Health. 2012;43(4):969-85.

21. Diekema D, Pfaller M, Schmitz F, Smayevsky J, Bell J, Jones R, et al. Survey of infections due to StaphylococcusSpecies: frequency of occurrence and antimicrobial susceptibility of isolates collected in the United States, Canada, Latin America, Europe, and the Western Pacific region for the SENTRY antimicrobial surveillance program, 1997-1999. Clin Infect Dis. 2001;32(s2):S114-32.

22. Holetz FB, Pessini GL, Sanches NR, Cortez DAG, Nakamura CV, Filho BP. Screening of some plants used in the Brazilian folk medicine for the treatment of infectious diseases. Mem Inst Oswaldo Cruz. 2002:97(7):1027-31.

23. Ham Y, Kim TJ. Inhibitory activity of monoacylglycerols on biofilm formation in Aeromonas hydrophila, Streptococcus mutans, Xanthomonas oryzae, and Yersinia enterocolitica. Springer Plus. 2016;5(1):1526.

24. Krasowska A, Sigler K. How microorganisms use hydrophobicity and what does this mean for human needs. Front Cell Infect Microbiol. 2014;4:112.

25. Schlievert P, Peterson M. Glycerol monolaurate antibacterial activity in broth and biofilm cultures. PLoS One. 2012;7(7):e40350.

26. Goc A, Niedzwiecki A, Rath M. In vitro evaluation of antibacterial activity of phytochemicals and micronutrients against Borrelia burgdorferi and Borrelia garinii. J Appl Microbiol. 2015;119(6):1561-72.

27. Seleem D, Chen E, Benso B, Pardi V, Murata R. In vitro evaluation of antifungal activity of monolaurin against Candida albicans biofilms. Peer J. 2016;4:e2148.

\section{Publisher's Note}

Springer Nature remains neutral with regard to jurisdictional claims in published maps and institutional affiliations. 